\author{
T. B. CALDWELL
}

\title{
THE SYNDICAT DES EMPLOYES DU COMMERCE ET DE L'INDUSTRIE (I887-I9I9)
}

\author{
A PIONEER FRENCH CATHOLIC TRADE UNION \\ OF WHITE-COLLAR WORKERS
}

I

The history of the Syndicat des Employés du Commerce et de l'Industrie is of interest both for its considerable success in organising clerical workers, ${ }^{1}$ who, in general, have been slow to recognise the value of trade unionism and on account of the dominant role it played in the history of the Christian trade-union movement in France. In 1920 the 30,000 clerical workers organised in the Féderation Française des Syndicats d'Employés Catholiques (which had developed from the SECI) accounted for nearly a third of the membership of the Confédération Frangaise des Travailleurs Cbrétiens. The SECI provided the new confederation with its chairman, Jules Zirnheld, its general secretary, Gaston Tessier and almost the whole of its secretariat; its principles, its attitudes, its methods exercised a powerful influence on the confederation until Tessier's retirement from the chairmanship in 1953. Although its action developed in the context of a growing body of official Catholic doctrine on social and industrial questions, from the Papal Encyclical Rerum Novarum of 1891 onwards, its approach was determined essentially by the pressure of the needs of its members; "practical organisation has always attracted it more than ideology" wrote its general secretary, Charles Viennet, in $1914 .^{2}$ In serving these needs it was deflected neither by the traditionalism of René de la Tour du Pin and Albert de Mun, who envisaged a corporate organisation of masters and men which would recreate the mediaeval guilds, nor by the democracy of Marc Sangnier, which, involving acceptance of the

\footnotetext{
1 For a definition of employé see Charles Viennet, Les Réformes Sociales concernant les Employés, in the report of the Semaine Sociale de France, IXe Session, Limoges 1912, Lyon 1912, p. 353. "The employé is the wage-earner who is concerned either with the handling, sale or delivery of manufactured goods, or with the keeping of accounts and with the administration of undertakings of all sorts."

${ }^{2}$ Charles Viennet, Le Syndicat des Employés du Commerce et de l'Industrie, Action Populaire, Série Snciale, No. 282, Paris 1915, p. 39.
} 
Revolution as well as the Republic, looked forward to a trade-union movement "strictly concerned with trade and industrial questions, democratic to the core and deeply respectful of all moral convictions" 1 and therefore implied membership of a broadly-based, democratic Confédération Générale du Travail. Nevertheless, in solving its problems as they arose the SECI evolved, and in so doing it gave to the Christian confederation a tradition of evolution, which led it finally, in 1964 , to the abandonment of its specifically religious character.

The SECI emerged tentatively and hesitantly, in the autumn of i887, from a complex of Catholic activities concerned with the spiritual, moral and material needs of young men. It leant heavily on priests, schoolteachers, business men and politicians and gave little indication that it had the makings of an autonomous association of wage-earners, even less that it would form the nucleus of a Christian trade-union confederation. "At the origin of the SECI," confessed Viennet, "you could have searched in vain for any brilliant doctrines or effective methods... Its beginnings were extremely painful. To tell the truth there was little or no understanding of what might be achieved by such an organisation." 2

The last third of the nineteenth century saw a rapid expansion of commerce, particularly in Paris. The numbers in commercial employment in France rose from just under a million in 1866 to over two million in $191 \mathrm{I}^{3}$ There was a considerable development of banking and insurance and in the capital the department store made its appearance. Meanwhile, the growth of primary education and post-primary education (the école primaire supérieure) was increasing the numbers of young men trained for and attuned to the more genteel white-collar occupations. But as the opportunity to enter such occupations increased their attraction began to diminish. The office and shop worker frequently worked very long hours, in conditions that were overcrowded and insalubrious; his contract of employment seldom made provision for overtime payments or for holidays, either weekly or annually; his employment was insecure, particularly in middle age and the man out of a job was often at the mercy of the private employment agency and of the employer who demanded a premium, thinly disguised as caution money; there was no system of apprenticeship or

${ }^{1}$ Marc Sangnier, Le Syndicalisme devant la République, Paris, n.d., p. 26.

2 Charles Viennet, op. cit., pp. I and 4.

' Henri Sée, Histoire Economique de la France, Tome 2, Les Temps Modernes, 17891914, Paris 1951, p. 287, n. 8. 
recognised professional training, and the white-collar worker lacked even the rudimentary legal protection that the statute book afforded to manual workers. ${ }^{1}$ With the establishment of the Paris Bourse du Travail in 1886 there was formed a Chambre Syndicale des Employés de la Seine, which took up the cause of the clerical workers, but the anarchist and socialist led trade unions affiliated to the Bourse du Travail had no appeal to devout Catholics.

Not only the trade-union movement but the Republic itself was hostile to the Catholic Church. Gambetta's old slogan "le cléricalisme, voila l'ennemi" cemented together the Republican majority in Parliament and provided common ground for Republicans and Socialists. A contemporary English observer noted that the Socialist newspapers displayed much more zeal for anti-clericalism than for collectivism or for social reform. ${ }^{2}$ In the years before the Ralliement many Catholics welcomed this confrontation between the Church and the Republic; in I 878 the chairman of the workers' circle in Montparnasse said, when moving a vote of thanks to Albert de Mun: "Thank you, my Lord, for your address... You have told us, and we have known it for a long time, that the evil from which we are suffering is the Revolution; not only did it destroy the joys of home and set society at war against all those who are placed legitimately in authority by God, but it left a legacy of ruin, suffering and misery. Yes, the Revolution is our enemy and we proclaim, with a loud voice, the necessity of the Christian Counter-Revolution." 3 In fact a Counter-Centenary of the Revolution was organised in 1889 and lists of grievances against the Republic were presented to provincial assemblies, where the duties of man were held up in place of the rights of man and where a society over which "the ruling class presided, by virtue of its capacity for leadership and its devotion to the general interests of the nation" was put forward as an alternative to republican political equality. ${ }^{4}$ Embattled Catholicism smacked at times of the ghetto and there were not lacking those who suggested that "the skilful and fraternal solicitude which the Jews

' See Ministère du Commerce, Rapports et documents sur le réglementation du travail dans les bureaux et magasins, Paris 190I. Ministère du Commerce, Les Associations professionnelles ouvrières, Tome IV, Paris I 904, Associations des employés, pp. 606-72 I. Charles Viennet, Les Veillés dans le Commerce. Rapport à l'Association Nationale Française pour la Protection Légale des Travailleurs. Paris i914. Charles Viennet, Les Réformes Sociales concernant les Employés.

2 J. E. C. Bodley, France, London 1899 , p. 645.

${ }^{3}$ L'Association Catholique, Revue des Questions Sociales et Ouvrières, Vol. V, 1878, p. 605 .

4 See Henri Rollet, L'Action Sociale des Catholiques en France, Vol. I, I 87 I-1901, Paris I948, Pp. I 30-134. 
brought to the provision of mutual help" should be copied by Catholics. ${ }^{1}$

The main attack on the Church was directed against its influence on education; the Acts of 16 June 188 I and 29 May 1882 made primary education compulsory and abolished religious teaching in the state schools, that of 30 October 1886 made provision, over a five-year period, for the withdrawal of clerical teachers from the boys' schools. 'The Church reacted vigorously by founding independent schools where the teaching of the Frires des Ecoles Cbrétiennes was continued. Money for the purpose poured in so quickly that at times it outran the supply of teachers, and on a number of occasions Brother Joseph, the head of the Institut des Frères, had to warn benefactors that "we cannot promise you teachers". ${ }^{2}$

The independent school shielded the child from the proselytising anticlerical influence of the instituteur; but after leaving school young people entered a world in which the beliefs and influence of the Church were violently attacked. ${ }^{3}$ A Papal message, in 1884 , urged the Frères to find ways of keeping up the Christian apostolate among these young people. "It is not when they are attending religious establishments that young men join these diabolical associations which are the principal cause of all the evil we see around us," said the Pope, "but it is after they have left school. It is therefore most important that there should be available for them some sort of association which will enable them to resist the seductions of the masonic sects... The various Catholic youth associations (cuvres de persévérance) are eminently suitable to achieve this end, and I want the Frères to establish them in all the towns where they have schools." 4 By 1894 it could be reported

\footnotetext{
'Joseph Pégat, in the Bulletin de l'Union des Syndicats du Commerce et de l'Industric, April 1887, quoted in Edouard Verdin, La Fondation du Syndicat des Employés du Commerce et de l'Industrie, Paris 1929, p. 40.

2 Quoted in Georges Rigault, Le Frère Joseph, Paris ig25, p. 2 I 5.

3 See, for example, Daniel Halévy's comment in Essais sur le Mouvement Ouvrier en France, Paris rgoI, pp. 172-175. "Under Louis-Philippe, Buchez could find Catholic workers to form a jewellers' co-operative. In 1849 , members of the journeymen's associations (compagnonnages), when they admitted to membership workers of a new trade, still specified that they should be Catholics. In I 869 the practice of the trade mass was suppressed in all the journeymen's associations and the secular spirit triumphed; it is in these twenty years of reaction that the people became atheist. More violent than their masters, Voltaire, Rousseau, Michelet, Quinet, Victor Hugo, they rejected the belief in the eternal soul and in God; any mention of the other world revolted them, as a wanton lie, told to lull them to sleep in this world... The name of God was so much detested that it was even difficult to read the poems of Victor Hugo [to working-class audiences]. They complained strongly about his deism."

4 Message to Cardinal Massaja, quoted by Brother Joseph in his circular of 21 November 1884, cited in Rigault, op. cit., pp. 246-247.
} 
that "from the point of view of the number of youth associations there is no chance of making further progress. At least in Paris and the suburbs they are established everywhere they can be, and new groups can only be formed where there are new schools." 1 There were at that time in Paris and the suburbs 53 associations, of which 30 had been founded since I 880 ; they were loosely bound together by the Conseil Général des Fuvres de la Jeunesse, presided over by the Archbishop of Paris and from January 1883 this council published a Bulletin Mensuel des CEuvres de la Jeunesse. The tone prevailing in the associations was, in general, protective and patronising. The Patronage de Grenelle, in a leaflet appealing for funds in 1894 , said of "its work of regeneration among more than five hundred young workers... More than ever, this work ... for apprentices and young people, is drawn to the attention of men of good will as one of the most effective remedies against the ruinous doctrines which, in drawing the workers away from the Christian faith, have aroused in them such wicked covetousness and hate against the upper classes."'2

The youth associations did not follow any single pattern, some were based on the parish, others were old scholars' associations, based on the school; one, the Association Saint-Benoit-Joseph-Labre, was an élite group, recruited from the most active and devoted members of the other associations. It merits special mention because it was to have a close link with the SECI. It was formed in I882, on the initiative of Brother Exupérien, the assistant director of the Institut des Frères, and it took its name from an 18 th century French saint, whose recent canonisation had produced a raucous outburst in the anticlerical press. Its members were selected for their piety and were trained to become militant workers for Christ and the Church; daily prayer and meditation, regular attendance at the sacraments, nights of adoration, pilgrimages of penance, days of retreat on the Frires' country estate at Athis-Mons were prescribed for a select group of young men, who were encouraged to regard themselves as an élite. ${ }^{3}$

The directors of the Church schools were concerned not only with the spiritual life of their pupils but also with their material welfare. As Edouard Verdin, an early member of the SECI, explained it: "the teaching orders ... had not only to find ways of maintaining the superior quality of the education, but even more important of ensuring that, on leaving school, their pupils were able to get good jobs. Otherwise their families would have been afraid that in entrusting

\footnotetext{
1 Marquis de Ségur, vice-chairman of the Conseil Général des CEurres de la Jeunesse, in the Bulletin Mensuel des Cuvres de la Jeunesse, I894, PP. I4I-I 42.

2 Leaflet, in L'Association Catholique, Vol. XXXVII, 1894.

${ }^{3}$ See Robert Frossard, L'Association de Saint-Labre 1882-1932, Paris n.d.
} 
their children to the Frères they would have been prejudicing their future." It was the usual practice therefore for the schools and the youth associations to help to find employment for pupils leaving school. In 1882 this service was extended, with the setting up of a Christian employment bureau; Brother Hiéron, ${ }^{2}$ a member of the Institut des Frères, acted as secretary and he had an office at I4, Rue des Petits-Carreaux, in a building which also housed a Church school and a number of youth associations. A committee of Catholic industrialists and business men was appointed to assist the work of the bureau, under the chairmanship of Abel Rainbeaux. ${ }^{3}$

During the first year of its operation the bureau placed 542 applicants in employment. ${ }^{4}$ It found that its services were in particular demand from pupils leaving the higher grade commercial schools, especially the newly opened Ecole Sainte-Clotilde, in the Rue de Grenelle, and it made effective use of the good will that Catholic business men could be expected to display towards young men whose moral character was attested by their priests and schoolteachers. Most of the applicants were placed with banks and wholesale firms, and the committee reported, with satisfaction, that they were all Christian firms and that there was no Sunday work. From its young charges the committee expected a high standard of behaviour and regular attendance at a youth association. It was not disappointed. In November I 885 it was reported that employment had been found for 995 clerical workers. "It is a whole army, made up, one might say, of an élite; each soldier comes back on Sunday for spiritual refreshment; many, inspired by their piety, do more than this and may be seen among the faithful who make the retreats at Athis. It is here, above all, that they find and strengthen those principles of fidelity which make them love their masters and their fellows."

The committee maintained a continuing concern for the welfare of

1 Verdin, op. cit., p. 22.

2 Brother Hiéron (Jean Giraudias) was born at Ravel-Salmerange, in the Auvergne, on 22 July 1830; he began his noviciate at Clermont on 9 September 1846 , served at Le Mans, Compiègne, and Paris, where he was particularly concerned with the care of apprentices and with evening classes; he took charge of the employment bureau in I882; he died on I January 1905. See Bulletin de l'Institut des Frères, No. I 18, July 1949.

3 Rainbeaux was chairman of the Conseil Général des CEuvres and a generous benefactor of the Church schools; he had made a fortune in coal-mining in the Pas-de-Calais. Other members of the committee were: Le Camus, Le Comte du Pont, Emile Dognin, Warée, Simmonot-Godard, Babeur, Jusserand de Winter, Gilbert, Lefébure, H. Lemoine, Louvet, Madrières, Regniault. See Bulletin Mensuel des Euvres, February I 883.

4830 applications for employment; 652 offers of employment; 542 placed in employment I engineer, 3 workshop managers, 3 foremen, 205 clerical workers, 330 manual workers.

See Bulletin Mensuel des Euvres, January I 883 .

5 Bulletin Mensuel des CEuvres, November I885. 
its young men; it asked that, once in employment, they would place great confidence in the wise advice it could give them; it reminded them that Brother Hiéron was at their disposition, in his office, every day from I 2.30 to 3 p.m., and it asked them to come to him, to explain their little difficulties and their needs, and it stressed that, before taking any extreme measure, such as leaving a job which appeared unsuitable, they should seek guidance and even ask for help; it promised them that they would not be disappointed. ${ }^{1}$

One further organisation needs to be mentioned, the Union des Syndicats du Commerce et de l'Industrie, formed in the summer of 1887 . Its instigator and secretary was a stockbroker and financial journalist, Joseph Pégat, who proposed a federal association of business men, covering a number of trades. Starting from the general premise that association was desirable among groups of people with a common interest, he argued that to work effectively the association must be limited to members who shared a common set of beliefs, and that although the Church did not have clear-cut and binding rules on all the vital questions which troubled the world of commerce and industry, its basic rules of charity, justice, respect for the rights of others and the keeping of the sabbath gave guidance in finding the right solutions, even to purely material questions. Associations of employers were formed for the furnishing, building, food, and printing and bookselling trades, and a mixed association, open to both employers and employees, was formed for commercial travellers. ${ }^{2}$

Catholic youth associations, and particularly the Association Saint Labre, Brother Hiéron's employment bureau and Pégat's industrial and commercial union were the parent bodies of the Syndicat des Employés du Commerce et de l'Industrie. The prime mover appears to have been Brother Hiéron, ${ }^{3}$ who held discussions during the summer of i 887 with members of a number of youth associations, about the problems faced by young men in clerical employment. He pressed them to form a trade union and after a sub-committee had met on so August to prepare a scheme, the inaugural meeting was held on 13 September, in Pégat's office at 30 , Rue des Bourdonnais. Brother Hiéron and Pégat were present, together with i 8 potential members, all of whom were

1 Ibid., February 1886.

${ }^{2}$ In August 1888 Pégat began the publication of a business news sheet entitled Correspondance Grise; the title was changed in 1891 to Compte-Rendu. It contained information on business activities, property sales, bankruptcies, liquidations, dividends and a digest of the financial press.

3 Despont, one of the founder members, recollected, on the occasion of the SECI's golden jubilee in 1937 that "we joined much to please the good Brother than because forming a trade union seemed to us to be of any use." L'Employé, September 1937. 
members of youth associations and of the élite Association Saint-Labre. ${ }^{1}$ They adopted a constitution drafted by Pégat, which restricted membership to Catholics while keeping within the legal definition of a trade union contained in the i 884 Act. $^{2}$ The SECI was to be open to clerical workers (employés), who were Catholics, of good character, who honoured their faith and who accepted the rules and the constitution; new members were to be admitted by the committee, on the proposition of two members. The aims were (a) to unite Catholic clerical workers, (b) to give them moral support, (c) to help them, as far as possible, to find employment with Catholic firms and (d) to organise lectures, courses etc. and anything else which might be

${ }^{1}$ Verdin, in La Fondation du Syndicat des Employés du Commerce et de l'Industrie, and all other writers refer to the 17 young men who were present at the inaugural meeting. Nevertheless Verdin quotes from the minutes a list of $x 8$ names. "The meeting was chaired by $M$. Dubois, assisted by M. Pégat, director of the setvices of the Union. There were present: MM. Dubois, Guignand Claudius, Despont, Boué, Martocq, Bizet, Schneckenburger, Lespinasse, Massu, Leraître, Guignand Charles, Chavanette, Hautreux, Pruneau, Grenier, Marécal Armand, Marécal Joseph, et Rempion." Verdin, op. cit., p. 45. The minutes, which were apparently in Verdin's possession when he wrote in 1929, cannot be traced.

2 The relevant provisions of the Act were: "Art. 2. Trade unions or associations may be formed freely, without governmental authorisation by persons, even exceeding twenty in number, who follow the same occupation, similar trades or allied occupations concerned in the making of particular products. Art. 3. Trade unions have, as their exclusive object, the study and defence of economic, industrial, commercial and agricultural interests. Art. 9. Breaches of the provisions of articles 2, $3 \ldots$ of the present Act will lead to the prosecution of the officers and officials of the union, who may be punished by a fine of from 16 to 200 francs. The court may, in addition, on the application of the Procureur de la République, pronounce the dissolution of the union."

The opinion of a Catholic lawyer was that "according to the text of the basic law (I 884) it is not illegal for Catholics to come together to form a trade union... I think that it is therefore clear that one can include in the rules the provisions that (a) an annual mass should be said, (b) that members who belong to secret societies should be excluded, (c) that Jews, Protestants, etc. should not be admitted to membership. However, while taking on this religious colouring, the union must preserve its concern with trade questions...If it transforms itself into an electoral committee and gives financial support to candidates and newspapers; if it turns itself into a religious brotherhood and organises retreats, sermons, pilgrimages; if, in a word, it devotes itself to political or religious activity it contravenes the 1884 Act. The Cour de Cassation held, in 1894, that it was a breach of the law when certain persons outside the industry were invited to meetings and took an active part in the work of the union... also that it was a breach of the law for the union to concern itself with questions outside the trade." A. Crétinon, in La Chronique du SudEst, 3 I March 1903, pp. 86-89.

The legality of the SECI was challenged on a number of occasions by the Chambre Syndicale des Employés de la Seine, in connection with elections to the Conseil Supérieur du Travail. These protests were rejected by the Minister of Commerce, Trouillot (ro August I903) and Dubief ( 5 March 1905). The latter ruled that the question was a matter for the courts and that, no adverse judgment having been made, the SECI should remain on the electoral lists. 
useful and appropriate to their needs. The contribution was fixed at 6 francs a year (about 9 shillings), payable in advance. The union was to be governed by a committee of between five and fifteen members, subject to general meetings, to be held at least once a quarter; its headquarters were to be at 30 , Rue des Bourdonnais, where Pégat, on behalf of the Union des Syndicats, offered accommodation rent-free.

At this first meeting the SECI displayed what was to be a characteristically flexible attitude to questions of practical organisation; it was laid down in the rules that members should observe the Sunday holiday, but when Schneckenburger, who occasionally worked on Sundays, asked whether this would make him ineligible for membership, the chairman replied that it was not, in fact obligatory, but that members should observe the Sunday holiday as far as possible.

\section{III}

The beginnings of the SECI were slow and painful. Its membership reached 125 in the first year, but this was soon eroded by resignations and the formation of a breakaway union, under the title of the Syndicat des Employés du Commerce et de l'Industrie de l'Union des Syndicats du Commerce et de l'Industrie; this organisation made no claim to be independent but placed itself patently under the control of the employers' Union des Syndicats. ${ }^{1}$ Martocq, the treasurer, reported to the

${ }^{1}$ Little is known about the Union des Syndicats or about the breakaway Syndicat des Employés, but it would appear that they favoured the establishment of a more restricted association of Catholics, employers and employees, whereas the SECI was moving towards a policy of protecting the economic interests of Catholic clerical workers, wherever they were employed. The chairman of the breakaway union told its first general meeting, on 2 March 1890 , that the real danger came from foreigners and enemies of the faith, who were isolating Catholics and closing avenues of employment to them; what was necessary, the secretary insisted, was that Catholics should group together to act in common on economic questions. See Ministère du Commerce, Les Associations Professionnelles Ouvrières, Tome IV, Paris x 904 , pp. 648 649 .

Pégat appears to have supported the SECI. At about this time the Union des Syndicats moved from 30, Rue des Bourdonnais to 46, Rue de l'Abre Sec; his comments in CompteRendu show sympathy for the demands made by workers on employers. On 26 March 189 I he wrote "we are not revolutionaries far from that, but we declare that we consider that the way in which workers, shop assistants, clerks etc., etc., in fact employees of all sorts are treated most of the time is contrary to our principles as good Christians". On 2 June 1891 he supported the demands of the employees of the Paris omnibus company, who were on strike for shorter hours. Later he expressed wholehearted approval for policy the SECI had adopted. Writing in the Bulletin for January - February i 897 he said that the SECI owed its success "to the absence of outside interference ... its leaders felt that they were strong enough and responsible enough to manage their own affairs... The clerical workers who formed the SECI were Catholics united in a commercial union, not young men belonging to a Catholic trade union. They were the Catholics, not the union." 
general meeting of the SECI on 26 March 1889 that only three members had paid their contributions and that the balance in hand was I 7 francs 75 centimes. "Contributions set off for the Suez Canal," he observed, in the metaphor of the day, "but they ended up at Panama and never reached the treasurer."1 But while neither the Union des Syndicats nor its satellite clerical workers' union survived for more than a few years the SECI revived and prospered. A new and energetic chairman was elected, Paul Baé, a twenty-seven year old jewellery salesman; the constitution was amended, to prevent the intrusion of "dangerous elements", 2 by limiting full membership to active members of a Catholic association (others, catboliques isolés, might still be admitted, as associate members, without the right to hold office); and the nominal roll was pruned to thirty members, of whom ten were associates. The Frères, confident in the leadership, gave full support to Baé's recruiting drive in the youth associations and encouraged the pupils leaving their commercial schools to join. ${ }^{3}$ There were still difficulties; a concert organised in November I 890 to raise money resulted in the loss of over 500 francs, and Baé, who found himself in increasing disagreement with his colleagues on the council, did not stand for re-election as chairman in $189 \mathrm{I}$. He was a man of autocratic temperament, whose ambition was to turn the SECI into a Christian co-operative community, which would find employment for all its members. The majority of the council, led by Verdin, opposed him and, after failing to secure the right of veto over its decisions, he withdrew. The way to success lay, as the majority of the council rightly saw, in the defence of the economic interests of Catholic clerical workers and membership rose to 230 in 1890 , to 1,000 in 1895 and to over 2,000 in 1900 .

The SECI was conceived by its founder, Brother Hiéron, and by its members, as an instrument to provide services for a restricted group of clerical workers, rather than as an instrument of collective bargaining. "We believe," said an editorial in the first number of the Bulletin du Syndicat des Employés du Commerce et de l'Industrie in November I 890 , "that the Union should be, for each of us, the instrument of security in employment, of a comfortable standard of living in the family, of advancement in the social position and, we believe too, that

${ }^{1}$ Quoted in Verdin, op. cit., p. 63.

${ }^{2}$ Verdin's phrase, op. cit., p. 66.

${ }^{3}$ See, for example, the reference in the Bulletin, June 1898 , to the work of Brother Pigménion, in the commercial schools of Saint-Roch, Saint-Michel, Saint-Antoine and SainteClotilde. "He introduces (the pupils) to the SECI, teaches them to know it, and to understand it, to want the support of its strength, and he shows them, in the light of the experience of similar associations, how firm and solid our's is." 
it should be the means of building up our personal fortunes." Alongside the employment bureau Brother Hiéron established, in September I 888, a friendly society, the Fraternité Commerciale. It was backed by a group of influential business men, headed by the wealthy textile manufacturer, Léon Harmel. The society was open to the commercial travellers' section of the Union des Syndicats as well as to members of the SECI, and for an entrance fee of from $s$ to ro francs, according to age, it offered sickness, disablement and retirement benefits, and medical attention, from a panel of five doctors. It leant heavily on its sponsors; from September 1888 to November 1890 the honorary members contributed 6,160 francs to the active members' contribution of $7 \mathrm{I} 5$ francs 50 centimes; the administrative costs were high, in 1893 217 francs ro centimes was paid out in benefits, while 1,682 francs 40 centimes was spent on administration. Although the society remained in existence it vegetated, with a static membership and declining interest from the honorary members; in 1902 , when the SECI had a membership of over 2,000 the Fraternité Commerciale mustered only 132 active members. ${ }^{1}$

In 1891 the SECI received a gift of 500 francs from an employers' association, the Union Fraternelle ${ }^{2}$ and this was used to establish a fund for interest-free loans to members. The fund was supplemented by collections taken at general meetings, by profits on social activities and by gifts; the loans to members were usually in the region of 50 to 200 francs, equivalent to between a week's and a month's wages.

Another service to members was termed co-operation. It began, modestly enough, in April I 890 , with an agreement under which a number of Paris stores, including the Belle Jardinière, the Maison $d u$

${ }^{1}$ See Ministère du Commerce, op. cit., pp. 646-648.

2 The Union Fraternelle was formed in $189 \mathrm{r}$, largely on the initiative of Léon Harmel. It had its headquarters at 14, Rue des Petits-Carreaux. It described its aims as being (i) religious, the deployment of the flag of the Sacred Heart by business men, (ii) the reform of commercial standards, by the practice of Christian duty towards customers and employees, and the encouragement of trade between members, (iii) to prepare the way for the return to guild principles and (iv) to put pressure on Parliament. In some ways it continued the work of the Union des Syndicats du Commerce et de l'Industrie, which was languishing. Unlike that body it was registered not as a trade association under the I 884 Act but as a joint stock company, whose purpose was the publication of a bulletin and an annual list of associated firms, and the provision of insurance services and information. It offered office accommodation and clerical assistance to members who wished to join together in trade associations, consumer societies, bulk-purchasing associations etc., an advertising service, for newspapers which wished to give the benefit of their columns only to Catholics, or at least only to people who respected Catholic beliefs, and an employment service. Its committee members included Dognin, Lefébure and Simmonot-Godard. See Annuaire de l'Union Fraternelle du Commerce et de l'Industrie, I 892 and 1893 . 
Pont Neuf and the Phares de la Bastille, granted a discount on purchases made by members. The discount was usually aroud $10 \%$ and the SECI itself retained an amount equal to $\mathrm{I} \%$ of the purchase price, before passing on the balance to the member. According to Verdin this form of discount trading was quite common with "more important organisations", but it needed the influence of Pégat and of Deshesdin (an honorary member of the Fraternite Commerciale) to negotiate this privilege for the SECI. ${ }^{1}$ In the year $1890-1891$ some 1,600 francs was paid out to about 200 members.

In February 1893 Brother Hiéron opened a small restaurant at I4, Rue des Petits-Carreaux, to provide a mid-day meal for the young men (and a meatless meal on Fridays). The SECI itself organised co-operative holidays from 1904 , taking over a sea-side hotel for members and their families. Although it was grandiloquent to describe these meagre activities as "a service of co-operation", they represented an aspiration which was realised in 1907, when the SECI acquired its own headquarters at 14bis, Boulevard Poissonnière and established a co-operative society, which, within a few years had an annual turnover of about E 25,000 and served over 300 meals a day in its restaurant.

Vocational training courses began in the autumn of 1893 , with a course in book-keeping, to which were later added courses in English, German, Spanish, shorthand, typewriting and political economy. Small grants were paid by the Paris municipal council and by the Societé d'Education et d'Enseignement, but most of the teaching was done voluntarily by friends of the union. ${ }^{2}$ A soldiers' committee looked after the interests of conscripts, organising courses of pre-military training and keeping in touch with members during their military service. A panel of lawyers gave free advice to members, on both trade and private questions.

Undoubtedly in the 1890 s the SECI was a highly dependent organisation. Its members were mostly young and inexperienced; out of 269 , in 1893,234 were under thirty years of age and 132 were between sixteen and twenty-one; most of the officers were still in their twenties. ${ }^{3}$ These young men had been model pupils of the Frères and were

1 Verdin, op. cit., pp. 75 and 81.

${ }^{2}$ See the article by Jean Lerolle, in Le Sillon, 1o July, I898, pp. 462-466. "The Union seeks to give its members some vocational and economic instruction, in order to enable them to surmount the difficulties of their lives; anyone who could come along to act as a voluntary teacher would be very welcome. That indeed would be a great act of solidarity."

${ }^{3}$ See Verdin, op. cit., p. $x_{4} \mathrm{x}$. 
pillars of the youth associations. Quite naturally, in moments of difficulty, they turned to their priests and teachers for guidance. "Not only did Canon Paguelle de Follenay [the director of the Association Saint-Labre] approve of the foundation of the SECI," wrote Verdin, "but he also wanted to give it regular help. Encouraging and advising the leaders, pushing on the hesitant, rallying the doubtful, he was, along with the dear brothers Alban and Hiéron, the powerful protector of the fragile edifice."1

The SECI grew up under the wing of an employers' association and depended upon its good will. Baé's circular to the youth associations, of I s June I 889 , pointed out that "the union had only been able to be formed when those who were taking the lead were convinced that they would be backed by a comparable group of employers, [who] ... had not only undertaken to come to the association to fill vacant situations, but had also, as a sign of their good will, founded a mutual aid society, the Fraternité Commerciale." In the absence of any system of collective bargaining protection of the members' interests was achieved largely by finding them jobs with good employers; "the union has faith", said a leading article in the Bulletin "in the effective support which has been promised and is being given by Christian employers."3

The SECI received considerable material help from outside; from I 887 to I $89 \mathrm{I}$ it had free accommodation and some clerical assistance from the Union des Syndicats; from I 891 to 1907 it was a tenant of the Union Fraternelle, at a nominal rent of one franc a year. Verdin reported to a Catholic congress in 1896 that "in 1892 , thanks to the generosity of the Frères we were able to have a full-time official on duty at our headquarters, and from that moment our activity really began to show some results."

This dependence was vividly and publicly demonstrated at the quarterly general meetings, when the platform was graced by the presence of distinguished friends - priests, like Canon Paguelle de Follenay and Brother Joseph, politicians, like Albert de Mun, Paul Lerolle and Deville (chairman of the Paris municipal council), business men, like Joseph Pégat, Emile Dognin and Warée, and even an exprefect of police, Albert Gigot. Many of these men had little understanding of the role of an independent trade union, and where they had such understanding they had scant sympathy for it. Their influence directed the SECI towards different ends.

Ibid., p. 72.

Ibid., p. 70 .

Bulletin, November $x 890$.

- Report to the Congrès Ouvrier Chrétien, Reims, 1896 , reprinted in the Bulletin Mensuel des Euvres, I 896, pp. 734-739. 
Some saw it as an "auvre de persévérance", a device for providing services for a particular group of young men, with the aim of encouraging them to maintain their religious beliefs and observances and to form a focus of Christian evidence in the offices, warehouses and shops where they were employed. Such a view was expressed by the Marquis de Ségur, in an article complimenting the SECI on its success; "it was destined", he said, "to play an important role in the youth associations, it had a profoundly religious character, and it would be doubly foolish for these Christian young men to carry their banner in their pocket."' Verdin, indeed, came near to sharing this view, when he told the general meeting on 26 June 189 I that "our union came wholly out of the youth associations directed by the dear brothers, that it has always been closely linked with their work, and that it can only live by continuing along this path. That we are deeply grateful, from the bottom of our hearts, to the Institut for founding this association, which so happily completes the range of institutions created for young people, and that we plead with them to continue and to give this one of their associations their good will and their protection, which will be the best guarantee of its success and above all of its Christian character."2

Others saw the Christian-led trade union as a political device to combat socialist influence in the labour movement. Social Catholics, through institutions like the Secrétariats Sociaux, offered help to independent trade unions in the form of office accommodation, administrative assistance, free use of space in journals for publicity. Membership of such free or independent trade unions was not usually restricted to Catholics and their independence was usually bartered away in return for the subsidies which kept them in existence. Such help was offered from 14, Rue des Petits-Carreaux in 1901, by a group entitled the Secrétariat Général des Syndicats Ouvriers, directed by Charles Claverie, which published a monthly journal, L'Echo des Syndicats. It was violently anti-socialist, it delivered homilies on the suffering caused by strikes and attacked the "gréviculteurs" who fomented them, it offered to supply employers with workers of guaranteed moral character and trade skill, hardly any of its contributions came from men following the trades that its associated unions organised, and a large amount of its space was devoted to advertising. One of the first contributors to this journal was Albert de Mun, who advocated the trade union as the most effective means of propaganda for those workers who did not wish, or were not able to participate in the intense

${ }^{1}$ Bulletin Mensuel des CEuvres, June I 890.

2 Verdin, op. cit., p. 126. 
life of the Catholic workers' circles. ${ }^{1}$ The SECI was at pains to dissociate itself from the activity which was carried on from an address that it shared; when the Echo des Syndicats launched a public appeal for funds in 1904 it served notice that, for its part, it had subsisted on its own resources for the past seventeen years and was in no way connected with the appeal. ${ }^{2}$

Others, again, saw the opportunity to use this experiment in tradeunion organisation as a basis for the recreation of that mythical community of interest between master and man, associated with the mediaeval guilds, or even more ambitiously to lay the foundation of a corporate regime. ${ }^{3}$ The view of the CEuvre des Cercles was expressed in a report drawn up by the Conseil d' Etudes in 1878 , calling for "the union of all individuals and all classes who work together in the process of production... The trade association must be Catholic," the report went on, "this is an indispensible condition for its vitality and the most certain guarantee that it will not become a weapon of revolution... [It] must achieve the union of employers and workers. One of the essential elements of such a reorganisation is the patronage by the higher classes, which, far from interfering with the exercise of the legitimate rights of the workers, procures for them guarantees of protection, which ensure their development and security... And finally, a last development which is reserved for the future ... the groups ... will form a powerful body, and in the Christian social state, which will recognise that there is a truth and a justice superior to the law of number, trade interests will regain the position that is rightly their's. The guilds will provide access to municipal and parliamentary representation, which is, at present, invaded by politicians."4 Paul Lerolle was reflecting such ideas when he told the general meeting of the SECI on 26 June 189 I that their association represented a return to healthy ideas and a condemnation of those of the Revolution, which had broken the link between master and man. ${ }^{5}$

${ }^{1}$ L'Echo des Syndicats, 25 January, $190 \mathrm{r}$.

2 L'Employé, November I904.

3 The term "le régime corporatif" was currently used by social Catholics in the 1880 and was defined by Herve Bazin as a regime giving recognition and representation in the state to the organisation of labour. See Minutes of the committee of the Euvre des Cercles, quoted in Rollet, op. cit., Vol. I, p. 68.

4 Rapport sur les associations professionnelles catholiques, 8 June 1878 , reprinted in L'Association Catholique, Vol. XIII (1 882), pp. 302-303.

5 Bulletin, July/August 1891 . 
Buffeted by these pressures from their patrons the young men who formed the SECI had no clear alternative concept of the function of a trade union; as Viennet said they had "little or no understanding of what might be achieved by such an organisation". ${ }^{1}$ They did however recognise that it was concerned with the conditions of their working lives; their spiritual and moral welfare was taken care of by other associations, to which they all belonged. Despont made the point sharply, when he told the members in 1889 ; "We are not here for mutual edification, or to stimulate piety, that is the business of the meetings of our youth associations; we are all good Catholics, that's understood, if we were not we should not be allowed in the union; but with that settled let us get on with the job of looking after our material interests."2 The Trade Union Act of 1884 obliged them to take at least nominal control of their organisation and with the self-assurance of the elect of the Association Saint-Labre they made that control real. What they lacked was an understanding of what trade unionism was about, and this they acquired through the SECI's most important and most characteristic institution, the study committee (commission d'études).

It was set up in January i $89 \circ$, on the suggestion of a new member, Edouard Verdin, to provide an opportunity for a fuller study of some of the problems facing the SECI than was possible at the meetings of the council. It applied itself, first of all, to an examination of the budget of the clerical worker. Initially members were elected by secret ballot, after presenting an essay on a given subject, to demonstrate their capacity to contribute to the work of the committee. Later this formal entrance requirement was dropped and the committee was opened to any member of the union who wished to attend. "It is composed", said an article in the Bulletin, "simply of those members who want to know something about the questions which directly concern the world of labour, and who wish to learn in order to understand and not for the pleasure of knowledge itself or for the acquisition of a diploma."3 It was an instrument of education rather than of policy-making. "The aim of the study committee," wrote Zirnheld, in 1898 , "an aim which is concealed but is effective, is to make each of us a man. By developing our practical knowledge, by helping us to make sane judgments, unprejudiced by the article in yesterday's newspaper or by the conversation just concluded, by getting us into the way of expressing clearly ideas which are just and well-understood, it beats into that

1 Viennet, op. cit., p. 4.

2 Bulletin Mensuel des CEuvres, January I 890.

${ }^{3}$ Bulletin, August I900, Charlet, L'Éducation Populaire. Notre Commission d'Études. 
ingot of raw gold that is human nature a personal value and a power to act, without which man is no more than an impotent fragment stuck to the mass... Study ... is not a need from which one is freed in childhood. What one learns on the school benches is but the building of knowledge, which, at a mature age, one must furnish with useful and sometimes with beautiful things if it is not to remain for ever empty and desolate."1

No doubt it came naturally to the young men from the écoles des Frères and the auvres de perséverance that their studies should be directed: their first maitre was Claudio Jannet, disciple of Le Play and professor of law in the University of Paris, he handed over his charge in 1893 to one of his students, Jean Lerolle, who was in turn succeeded in 1908 by Georges Piot. "The committee met once a month, on Friday evening, at about nine o'clock", recollected Lerolle, “... Brother Hiéron, who had been behind the formation of the union, and who remained its devoted and vigilant friend, said a prayer and then sat a little apart, as if to show that he respected the young men's liberty. Verdin, who took the chair, opened the session and the committee got down to work. To begin with, they asked me to give a talk on the subject before the meeting; the members of the committee were a little shy of speaking. Then they decided to present papers themselves and very quickly they produced some excellent work. The reading of the paper was followed by a discussion, which was invariably cordial and lively; I brought to it my theoretical knowledge, the members of the committee brought their experience of life and their knowledge of the ordinary people of Paris, and together, in the same spirit, in a common effort, and I can say in complete mutual trust, we sought, through study, to formulate our personal convictions and to draw up a programme of action for the union. We would have carried on until a late hour had not Brother Hiéron taken care to see that we broke up soon after ten o'clock... Out in the street we separated. Some of us, who lived on the Left Bank, Verdin, Viennet, Blanc ... went home together; we passed through the gardens of the quiet and majestic Louvre and over the river, continuing the discussion. Our group got smaller and smaller until Verdin and I were left alone in the avenues of our seventh arrondissement." 2

Lerolle had just taken his degree in law; he was the son of Paul Lerolle, a prominent Catholic politician, who served on the Paris municipal council and later became a member of parliament. $\mathrm{He}$ himself went on to play a prominent part in the social Catholic movement, as chairman of the Association Catbolique de la Jeunesse

1 Bulletin, July 1898 ; Jules Zirnheld, Simples Réflexions.

${ }^{2}$ L'Employé, September 1937. 
Française and of the Paris Secrétariat Social, and as a member of parliament. He was in advance of most of his fellow social Catholics in rejecting the mixed union of employers and workers and in advocating strong, independent workers' trade unions. Weak trade unions engendered social conflict, he told the ACJF, because though they were capable of stirring up strikes they lacked the power to conclude collective agreements, still less to ensure that agreements were observed. He also warned against confusing professional action and confessional action, and against using the trade-union label to conceal a political committee. ${ }^{1}$ These views reflected the experience he gained in the discussions with the SECI.

From 1893 to 1897 Lerolle acted as tutor to the study group, giving a talk, leading the discussion and preparing the monthly report for the Bulletin. In 1897 the members began to make their own contributions; Jules Zirnheld began, with a paper on the organisation of commerce, in which he made a powerful plea for the creation of a new type of institution, a joint industrial council, in which representatives of employers and of workers would come together to discuss matters of common interest. "For a long time", said Zirnheld, "England has been ahead of us in this respect and we already borrow enough useless things from our neighbours across the Channel to be able to assimilate ideas of this sort." 2 Other members followed; Verdin, Guillebert, Viennet, Despont, Armand, Tessier, discussing the contract of employment, collective bargaining, hours of work, compulsory arbitration, strikes, profit-sharing, apprenticeship, vocational training, cooperation, working-class housing, pensions and other subjects. Lerolle brought along his colleagues and close personal links were formed between leading figures in the social Catholic movement and members of the SECI; Martin Saint-Léon, Henri Bazire, Ludovic de Cotenson, Henri de Gaillhard Bancel, Georges Blondel, Raoul Jay, Marc Sangnier, Auguste Champetier de Ribes, Georges Piot took part in the discussions and came to know the "syndicat des Petits-Carreaux".

The educational achievement is clear from the comments of Piot, who took over the chairmanship in 1903 . "I came to the chairmanship as a young barrister", he wrote, "and I was immediately overwhelmed both by the detailed documentary research and by the practical experience which went, each month, into the carefully prepared papers; clearly they had taken many hours of work. It was obvious to me at once that each of them knew much more than I did about the subject they were introducing ... and that my role, as chairman, was

\footnotetext{
${ }^{1}$ Action Catholique de la Jeunesse Française, Compte-Rendu du ler Congrès Social National, Chalon 7-ro May, 1903, pp. 7-13.

2 Bulletin, October 1897 .
} 
above all to make sure that in the lively discussion which never failed to follow the reading of the paper, there was order, method and clarity, and to point out the general ideas which emerged from the lecturer's conclusions and from the discussion in the meeting.

There is no doubt at all that the study committee served as a school of trade-union education for all those who, over the last thirty years launched, led and spread the Christian trade-union movement."1

This was a period of ferment in popular education, in the bourses $d u$ travail, in the universités populaires, in the Catholic cercles d'études sociales and instituts populaires, study was in the air and the intellectuals went to the people. The contribution of the SECI was not insignificant. The study committee produced a body of men confident in their own abilities, trained to collect, weigh and analyse evidence, well-fitted to lead a trade union committed to a reformist programme, based on the negotiation of agreements with employers and on the maintenance of pressure on government and legislature for the extension of labour legislation. It applied itself almost entirely to the study of practical questions affecting the life and work of the clerical worker, and it avoided the abstract discussions so much beloved by the social Catholic movement; even the papal encyclical Rerum Novarum passed almost un-noticed, and the occasional references to it served more to provide post-facto justification for policies arrived at empirically than to provide a basis for policy making. It brought the intellectuals into touch with the immediate pressing needs of the "white-collar proletariat" 2 the phrase is that of the general secretary, Viennet - and it gave them confidence in the sound leadership of this Catholic trade union.

A Catholic trade union congress, held under Zirnheld's chairmanship r 909, laid great emphasis on the need for sound organisation. "The rules must be carefully drawn up, the council must be regularly elected, the books must be well-kept and properly balanced; all these

${ }^{1}$ L'Employé, September I937.

2 Charles Viennet, Chez les Employés, in Bulletin Mensuel des Euvres, 1914, pp. 30-32. "The clerical worker who wants to rise, and who has the means (professional skill, luck, help etc.) is distinguished sharply from the one who remains, for a large number of reasons, a clerical worker all his life. Because of the development of commerce and industry this last category has increased considerably over the last fifty years, with the result that there is now a white-collar proletariat. Because this white-collar proletariat has a different background and different reactions from the manual worker proletariat, its demands are expressed in a particular idiom, doubtless more timid than that of the manual worker, but above all influenced by education and love of security." 
things demand a body of adequately paid officers." 1 These recommendations were a projection of the organisation achieved by the SECI.

The effective policy-making body was the council, elected by the general meeting; it consisted originally of 7 members (1887) and was extended to II and then to $2 \mathrm{I}$, each serving a three-year term, with one-third retiring annually. The council elected an executive committee (bureau), which consisted, in 1914, of a chairman, two vice-chairmen, a secretary-archivist, a treasurer and a deputy treasurer. The officers and the council were responsible to the general meeting of members, held quarterly, but this tended to be a rather formal occasion, when distinguished public men adorned the platform, from which the officers made their reports to a docile and respectful audience. ${ }^{2}$ The need for discipline and leadership was accepted; Baé wrote in the Bulletin in March I891: "It is indispensible that all members should place complete confidence in the leadership. Of course it is necessary that the leadership should be enlightened and well-informed, and for that we count on the help of everybody. We know of no society, large or small, which prospers without insisting strictly on the greatest deference, and even the most respectful obedience to the established authority." And, if Baés autocratic leadership gave way to the collective leadership of his colleagues, they insisted, no less than he, on the need for discipline and deference. Viennet, reflecting in later years on the reasons for the SECI's success, gave pride of place to its discipline and cohesion $^{3}$ and Zirnheld, reporting on the work of the soldiers' committee went so far as to say that "self-sacrifice and discipline were just as necessary in an army as they were in a trade union". ${ }^{4}$ But this centralisation of authority was considerably tempered by opening the sub-committees of the council, including the key study committee, to any members who were interested in attending. The result was that the SECI was governed by an open-ended oligarchy, to which the most able young recruits, like Zirnheld and Tessier, quickly gravitated.

Some measure of decentralisation was provided by the trade groups, which met independently to discuss matters of common interest; a

${ }^{1}$ Report of the Congrès d'Action Syndicale, 30 and 31 May 1909, in L'Employé, July 1909. ${ }^{2}$ See, for example, Verdin's description of the general meeting of 26 June 1891 . "Presiding over the assembly was M. Paul Lerolle, member of the Paris municipal council... Around him on the platform were the Reverend Father du Lac, who was later to found the mixed trade union for the clothing trade, Canon Paguelle de Follenay, Brothers Exupérien, Alban, Hiéton, the Abbé de Bessonie, Messrs E. Dognin, Pégat, Lefranc and several priests and laymen who were prominent in the youth associations... There were Iso people in the hall [of the Francs Bourgeois commercial school]." Verdin, op. cit., p. i 8. (At this time the SECI had about 320 members).

3 Viennet, op. cit., p. 39.

4'Employé, February 1906. 
group for book-keepers and accountants was set up in 1890 ; groups for administration and the fabric trade were added in 1894, for commercial travellers, the building, food, clothing and printing trades in 1895 and for shop assistants and life and fire insurance employees in 1902.

In I 889, on Baé's initiative, delegates to the youth associations were appointed and by the end of 189130 delegates covered more than half of the associations in Paris and the suburbs. "Their role is very important", wrote Verdin in 1892 , "they collect the contributions, they are the life blood of the union, because we make a point of keeping them informed of anything that might interest our members and they bring information back. Moreover it is through them that we get most of our new members." 1

An external relations committee, set up in 1903 , encouraged the formation of sections in the provinces and there were 14 of these in I9 3 , with a membership of 807 .

From its early years the SECI was able to draw on the services of a paid staff. In May i 890 some of the work of administration, which was beginning to impose a heavy burden on the officers, was handed over to one of Pégat's clerks and the council set aside one franc a member to pay him. Two years later, "thanks to the generosity of the Institut des Freres", a full-time officer was appointed (Guillebert). The establishment of the co-operative society in 1907 imposed an extra administrative burden, but also provided extra resources; "the cooperative society", wrote Viennet, "bears the cost of considerable expenses which would be beyond the capacity of the union", 2 and by I9 I4 there was a paid staff of four, a general-secretary, a cashieraccountant, an employment bureau manager and a collector. Appointments to these offices were made by the council.

The SECI took great pride in its financial stability and independence. According the figures given by Guillebert in the report to the Ministry of Commerce the treasurer collected about three quarters of the contributions which fell due over the period 1891 to 1902 . This was a remarkable achievement by any standards and particularly by those of the French trade-union movement. Two factors made it possible. First, the growth of the SECI out of the youth association, a body that itself depended on voluntary contributions and was adept in the art of extracting money from the faithful. The delegate who collected contributions at the meetings of the youth association had all the authority of the church behind him. Second was the device of discount on purchases; the SECI collected the discount on behalf of

1 Bulletin Mensuel des CEuvres, I892, p. 357.

Viennet, op. cit., p. 36. 
its members and, before distributing it, retained a sum sufficient to cover the union contribution for the current year. So, many members were able to pay their contributions painlessly as they spent. In I9O2, according to Guillebert's figures, contributions paid amounted to 8,914 francs, members' purchases amounted to I63,000 francs, on which a dividend of I I,000 francs was collected.

There were a number of supplementary sources of income in addition to that from members' contributions. A proportion of the dividend was retained; this amounted to 1,630 francs in 1902 , nearly one fifth of the amount collected in contributions. There was the income from sales of the Bulletin. "Last year", reported Verdin to the Reims Christian workers' congress in 1896 , "we could only make both ends meet with difficulty, but our treasurer managed to balance the budget by introducing subscriptions to the Bulletin, which, thanks to good publicity, produced good results."1 The SECI's links with the business world, through the social Catholic movement and the youth associations, which had already ensured security of employment and advancement for many of its members (Verdin and Zirnheld were employed in the Banque de France and the latter moved, with Dognin's help, to the Michelin company in 1909) brought in a flood of subscriptions. The Bulletin reported that "in response to requests from our devoted friends the Banque de France, the Crédit Lyonnais, the Société Générale, the Compagnies des Chemins de Fer Paris-Lyon-Marseille et du Midi, the Cbambre Syndicale des Tissus, the directors of the Bon Marché, of the Louvre and of other important firms, numbers of business men and the Institut des Frères all took out subscriptions."2 In July ${ }_{1} 898$ Jean Lerolle wrote in Le Sillon: "The SECI needs resources; [those who would like to co-operate] can help it to obtain them by subscribing, and by getting their friends to subscribe to the Bulletin (10 francs a year)." In I90 I about 6,000 copies of the Bulletin were printed, for a membership of 2,258 , which suggests that the income from this source could have matched that from members' contributions. ${ }^{3}$

${ }^{1}$ Verdin's report to the Reims Congrès Ouvrier Chrétien, 1896 , quoted in the Bulletin Mensuel des CEuvres, I896, p. 738.

2 Bulletin, May-June I895.

${ }^{3}$ Zirnheld (who was treasurer at the time) says that the SECI's income was 26,608 francs in 1906. (Cinquante Années de Syndicalisme Chrétien, Paris, 1937, P. 5I). The membership was 3,974. If one makes allowance for members undergoing military service and assumes that three-quarters of the contributions due were collected it may be estimated that about 15,000 francs represented members' contributions; the estimated share of dividends on members' purchases amounts to 2,500 francs, which leaves just over 9,000 francs to come from subscriptions to the Bulletin and from other sources. Cf. Guillebert's figures for contributions due and paid, in Appendix. 
Finally there were the gifts and the subsidies in kind. Until I 907 the SECI either had accommodation rent-free or at a nominal rent; the Institut des Frires appears, at least in the early years, to have met the cost of employing a full-time agent; the benevolent fund was launched with a gift from the Union Fraternelle and fed with collections made at general meetings, and it seems unlikely that the distinguished visitors, of whose presence at these meetings the union was so proud, failed to dip into their pockets. But it must be said that the union was at pains to avoid accepting any payment which might have prejudiced its legal position and that as its membership grew and the range of its activities widened, it came to rely increasingly on its own resources. The most important step in this direction was taken in 1907, when the SECI moved to I 4 bis, Boulevard Poissonnière, which was leased at an annual rental of 9,500 francs. On Zirnheld's advice the council decided to form a co-operative society, with a capital of 5,000 francs (later doubled), seven tenths of which was held by the SECI and the remainder by individual council members; the cost of installation came to 60,000 francs and this was met by a loan, raised among the members. The co-operative society made a loss of i 2,000 francs on the first year, it broke even in the second year and had a surplus of 7,500 francs in the third year. Within seven years the loan from the members had been redeemed and the co-operative society was providing a firm financial base for the SECI's operations.

When an inter-union congress discussed the question of finance in I 908, Zirnheld, speaking with all the authority of the treasurer of the SECI, told the delegates that it was proper for a trade union to accept financial aid from private sources, provided that it was offered without conditions. ${ }^{1}$ There is no evidence to suggest that such financial assistance as was received by the SECI in any way deflected its leaders from the course they had chosen to follow in defending the economic interests of their members.

\section{VII}

By the turn of the century the SECI was well established and its leaders had a clear vision of its purpose. Membership was restricted to Catholics. The precise form of the restriction varied; up to 1889 it was only necessary to be a Catholic, of good character, who honoured the faith; from 1889 to 1900 it was necessary to be an active member of a Catholic youth association, or to serve a three-year probationary period as an associate member; after 1900 membership was open to anyone commonly acknowledged to be a Catholic (notoirement catboli-

${ }^{2}$ L'Employé, July xgog. 
que). This restriction arose from the circumstances of the SECI's foundation and it was maintained because Catholics in general were hostile to the socialist and anarchist-led trade unions of the Bourse du Travail and the Confédération Générale du Travail; "hence the idea of founding a trade union reserved exclusively for Catholic clerical workers, which they could join in full confidence". ${ }^{1}$ This hostility was based on differences of principle about the forms that trade union action should take. "If the trade-union question was merely ... as certain socialists affirm it to be ... a bread and butter question," said Zirnheld, "there would be no problem; but the trade-union question is a social question, and the consequences which follow, the problems which it raises, can be solved in contradictory way according as to whether they are looked at in the light of the morality of the gospel or of materialist doctrine or socialist dogma." 2 The differences were sharpened by the publication of the papal encyclical Rerum Novarum, which condemned socialism as a false remedy for the ills of society; they hinged particularly on Catholic opposition to violence, to the general strike and to the concept of the class war. They were reinforced by the distrust shown towards practising Catholics by the leaders of trade unions affiliated to the CGT. Marc Sangnier's policy of penetration of the CGT found no response in the ranks of the SECI, but even the Sillonists found that they were viewed with distrust, as when the Chambre Syndicale des Employés de Commerce at Angers decided in 1908 that "in order to preserve its militant character" it could not accept Sillonists as members; 22 members were thereupon excluded and their contributions were returned. ${ }^{3}$

Certain positive advantages flowed from this restriction. The common background of the école des Frères and the auvres de persévérance gave to the SECI cohesion and homogeneity, reduced the risk of disagreement and created "a feeling of mutual respect among the members".4 They were, as Pégat told them, "all recruited from the same flock, there were no black sheep" 5 and their habit of "deference and respectful obedience" 6 to established authority eased the problems of leadership.

In spite of this restriction of membership the SECI insisted that its concern was with the condition of its members' working lives and not

1 Zimheld, addressing the 1903 International Congress of Clerical Workers' Unions, Brussels, quoted in C. Claverie, Syndicat des Employés du Commerce et de l'Industrie, Monographie Syndicale, L'Action Populaire, Paris, n.d., p. 34.

${ }^{2}$ L'Association Catholique, Vol. XLV (igo8), pp. I94-Igs.

${ }^{3}$ Marc Sangnier, Le Syndicalisme devant la République, Paris, n.d., p. $82 \mathrm{n}$.

4 Bulletin, March I 891 .

5 Bulletin, January-February 1897 .

6 Bulletin, March, I891. 
with the state of their souls and the fact that there was no need to bother about their loyalty to Catholic principles absolved the leaders from the need to proselytise and freed them to attend to trade matters. This is not to say that the SECI did not take part in religious activities. It sent a delegation to a special mass for youth organisations, held in the Basilica of the Sacré Caur on 29 June $189^{\circ}$; they carried their flag, the sacred heart on the tricolour, and in so doing the struck a blow, avant l'beure for the Ralliement, since according to Verdin, it was the first time that the flag of the Republic had been carried into the church of the national vow. ${ }^{1}$ The flag was carried again by the delegation taking part in the working class pilgrimage to Rome in September г 891. Two years later a tablet was unveiled on the wall of the chapel of Notre-Dame d'Athis, recording the union's thanks to its patron Saint Michael, on having obtained the number of members for which it had asked, and thereafter the feast of Saint Michael was celebrated annually. Not only to its opponents but also to some of its friends the SECI had the appearance of a religious organisation; an article in the Catholic journal La Corporation which referred to the union's own journal as the product of the young men from the Catholic youth association in the Rue des Petits-Carreaux, provoked the riposte "the youth association of the Rue des Petits-Carreaux does not write for L'Employé. This association and the SECI occupy the same building, but they have nothing in common except the entrance hall."2

At an early stage the SECI's independence in relation to its patrons was challenged and it replied with a significant declaration of autonomy. In the spring of 189 I Pégat moved his office and the SECI decided that, instead of moving with him, they should accept the offer of the Union Fraternelle to provide accommodation at i4 Rue des PetitsCarreaux. Soon after the move, on 23 April i 89i representatives of the SECI were invited to meet the committee of the Union Fraternelle; Baé, Martocq and Verdin attended from the one side, Léon Harmel, Emile Dognin and the secretary Hyacinthe Lefranc from the other. Lefranc read a memorandum in which it was argued that the SECI was one of the many Catholic associations founded by the Freres, that it was, in effect, the partner in the economic field of the Association Saint-Labre in the spiritual field and that it was therefore appropriate that the Union Fraternelle should use the SECI, which for legal reasons had to take the form of a trade union, as a means of spreading Christianity in the world of labour. Hence it followed that the SECI should accept the authority of a chaplain and a supervisory committee (comité protecteur), composed of Frères, ecclesiastics and laymen, de-

1 Verdin, op. cit., p. 85.

2 L'Employé, August $190 \mathrm{I}$. 
voted to the interests of the clerical workers. On economic and trade questions the initiative would come primarily from the SECI, and the advice of the committee would not be binding, but on religious and moral questions control would be in the hands of the committee. The proposal was combined with the offer to expand the social services offered to members and their families, through the Union Fraternelle. Such a proposal was entirely in line with the paternal attitude of the social Catholic movement. The leaders of the SECI viewed it with distaste, they responded tactfully but firmly, asking for time to consider it. They consulted Canon Paguelle de Follenay and the Frères and in due course sent a written reply rejecting the proposal, on the grounds that moral and religious direction was already provided through the Catholic youth association to which all full members of the SECI belonged, and that the sort of control envisaged by the Union Fraternelle would weaken their organisation, by limiting the authority of the leadership over the members and would open the way to its judicial dissolution, as an illegal association. No more was heard of the proposal. $^{1}$

The question of outside supervision was however raised again in 1906. With the expulsion of the Frères, following the separation of church and state and the dissolution of the religious orders, a lay committee took over the building at I4, Rue des Petits-Carreaux and it demanded the right to supervise the SECI's publications. The union refused to accept the demand and moved, in the following year to its own headquarters at $14 \mathrm{bis,} \mathrm{Boulevard} \mathrm{Poissonnière.}{ }^{2}$

Having declared its independence of its religious patrons the SECI showed an equal determination to avoid the taint of yellow trade unionism. The Jaunes had originated in a miners' strike at Montceaules-Mines in 1899 and a Fédération Nationale des Jaunes de France had been formed in I 902 . Its leaders were Pierre Biétry, a one-time revolutionary trade unionist and a watchmaker by trade, Steens, of the printers, Verleye, of the draughtsmen, Jarry, of the clerical workers and Bresson, of the clerks in the gas supply industry. Its programme called for (I) the improvement of the conditions of the working class, (2) profit-sharing, (3) opposition to politically inspired strikes and to any strikes not made necessary by the intransigeance of the employers, (4) the fixing of hours of work by the trades, in agreement between unions of employers and of workers, ( 5 ) the development of friendly societies and other forms of mutual aid, (6) the social education of the workers, freedom of association, educational freedom, freedom of

1 The incident is described at length by Verdin, op. cit., pp. I I 2-1 I s. He adds "no whisper of this ever got beyond the meetings of the Council [of the SECI]."

${ }^{2}$ Zirnheld, op. cit., p. so. 
conscience and the right to own property. The federation received substantial financial help from employers, particularly Gaston Japy, the watch and clock manufacturer from the Jura and Laroche-Joubert, the paper-maker from Angoulême; it was violently anti-socialist and anti-semitic and it became little more than a strike-breaking organisation. ${ }^{1}$ Nevertheless it was welcomed enthusiastically by many social Catholics. Albert de Mun said of the strike at Montceau-les-Mines: "The yellow trade unions have been the citadel defending the freedom of labour ..... thanks to them wise and peaceloving workers have become aware of their rights and of their strength ..... they have roused and organised public opinion; financial contributions have come from all sides... from all ranks of society, employers and workers, producers and consumers, all of them felt that what was happening at Montceau-les-Mines, in this clash of two trade unions, was of great significance for the future."' $\mathrm{P}$. de Bricourt, writing in $L^{\prime}$ Association Catholique, claimed that "between the demands [of the yellow unions] and the conclusions of the social Catholics there [was] no essential divergence ..... the efforts being made by the yellow [unions]" he concluded "deserve our most sympathetic attention."3

This was not the view of the SECI and in an article in Le Sillon, entitled the Yellow Peril, Viennet produced a devastating indictment of the yellow unions, which showed a very firm grasp of what autonomous trade unionism involved and no illusions about the weakness of social Catholic support for independent working-class action. He indentified, as "one of the deepest causes of the failure of trade unionism ... the abdication by the workers of their responsibilities, in favour of professional agitators." "The only gain", he said, "is that somebody gets a well-paid job ... the methods are the same, whether they are the Reds or the Yellows ... the same scorn for the conscience of the working class, the same prejudice over the incapacity of the workers to defend their interests themselves, to run and manage their own trade unions without interference... Far be it from us to want to uphold the class struggle or to claim that no agreement is possible between employers and workers. Quite the opposite, we recognise that they have common interests, that they must both, for example, hope for the prosperity of the commercial and industrial undertakings from which they get their livelihood. But they have also, and do not let us forget it, interests which are different and quite often conflicting. Now so far as the workers are concerned the defence of these interests is only possible if they conserve their independence;

${ }^{1}$ See Pierre Biétry, Les Jaunes de France et la Question Ouvrière, Paris, I go6.

2 Speech to the Union de la Paix Sociale, reported in L'Echo des Syndicats, 25 June 1901.

${ }^{3}$ L'Association Catholique, Vol. LXI (1906), p. 172. 
they must feel themselves free from any commitment when they discuss with the employers questions such as wages and other matters. How can this be the case when the alliance with the employers is cemented with subsidies, which, if they are without strings in the minds of some of those who pay them, in the minds of others amount to an insurance premium against a strike or a wage claim... Regular subsidies, wherever they come from, paralyse the initiative of trade associations. Yellow trade unions are the instrument of Conservative politicians, they have a negative programme ... anti-socialism. What is so distressing is to see the inexplicable infatuation of a certain number of Catholics. Ah, you can really see that there is more joy among them for one socialist who makes a noisy renunciation of his convictions, than for ninety-nine Christians who labour and persevere in silence... Do the Catholics who advocate these yellow ideas think, by doing this, of bringing about an improvement in the condition of the working class? Do they commit themselves to supporting its basic demands? Or rather do they make the same mistake as the politicians to whom we referred a moment ago and are they not expecting from this movement results in no way connected with trade questions. We lean all the more heavily towards the latter hypothesis because we have heard certain eminent Catholics state publicly that at the present time the non-revolutionary trade unions should engage in political activity. In their view trade unions are organisations ... which can follow a political line all the more effectively because it is less apparent... To sum up, we should be wrong if we saw the future through yellowcoloured spectacles. This fragile structure has been erected in haste, on sand, and no doubt it will collapse of its own accord ... but the result will be to compromise trade unionism and to hold it back for a long time. Whatever happens it was necessary that the workers should join in a debate which concerns them in a most direct fashion and that they should say that they will not agree to be dragged along by the first person who comes, as they are being asked to do, and that they should make it clear, that, neither Red nor Yellow, they intend to work with their own resources for their social and economic emancipation."1

"An old trade unionist" (Zirnheld in fact) replied in L'Employé to Bricourt's article, and his argument marked a significant stage in the evolution of the SECI's policy on strike action: "The Jaunes condemn the use of the strike ... we believe that this extreme weapon is sometimes necessary, and that a labour organisation, even one perfectly developed, could not do away completely with the use of it", and in

1 Charles Viennet, Le Péril Jaune, in Le Sillon, 25 July 1906. 
support of this view he quoted the example of the English trade unions. ${ }^{1}$

The SECI dissociated itself from the Jaunes because it considered that these trade unions were not part of the independent labour movement; at the same time, while insisting on its right to remain separate in organisation, it made moves to associate itself with other genuine trade unions. The formula of unity of action (unité d'action) was explained by Viennet in an article in $L$ 'Association Catbolique. "It is well known," he said, "that if recruitment to the union is Catholic its action is exclusively professional. And it is utterly wrong to accuse it of standing aside from the world of labour. Quite the contrary, its policy is to act in concert, to the fullest extent possible, with different organisations of clerical and manual workers. This is what the SECI says and this is what it does. In all the national and international congresses in which it has taken part its delegates have chaired committees reporting on important questions... It can be seen therefore that the union is working hard for unity of action in the trade."2

The first formal contact with non-Catholic trade unions was made in 1899 , when the SECI sent a delegation to a conference on the conseils des prud'bommes, ${ }^{3}$ held at the Bourse du Travail in Paris; Guillebert was appointed as chairman of one of the committees (rapporteur). In the following year a strong delegation attended the sixth national congress of the Féderation Nationale des Employés and the first congress of the Féderation Internationale des Employés, which were held concurrently from 2 to 9 September at the Bourse $d u$ Travail in Paris. Zirnheld, reporting in the Bulletin said that the two basic principles which emerged at the national congress were, first, the support for political action by trade unions (advocated by the general secretary, Victor Dalle), and second, an implacable hostility towards the employers (expressed by a majority of delegates from the floor). The SECI opposed both these principles, but, said Zirnheld, "if the personal ideas [of the delegates] have led them to extreme solutions which we do not accept, nevertheless, in remembering the hours spent working together, we feel towards them the mutual esteem of men fighting, by legal means, for the same end."4 The esteem, however, was not mutual, and at the next congress of the Fédération Nationale, I 2 to

1 L'Employé, s June I go6.

${ }^{2}$ L'Association Catholique, Vol. LXV (1908), pp. 187-188.

${ }^{8}$ The conseils des prud'hommes were local trade tribunals, abolished by the Revolution but re-established by Napoleon in 1809 , whose function was to resolve individual disputes between employers and workers or apprentices; they consisted of equal numbers of employer and worker representatives, separately elected within trade colleges. Conseils des prud'hommes for commerce were set up by an Act of 27 March 1907.

4 Bulletin, October 1900 . 
I4 July 1902, the delegates voted unanimously (all fourteen of them) for the refusal of credentials to the SECI. The delegates argued that an organisation which demanded from its members birth and baptismal certificates was not a trade union and that its constitution was contrary to the law; that it was an absolute negation of liberty, because it demanded of its members attendance at Mass; that it wished to return to the old guild ideas; that it was almost a yellow union (or worse, a black union); that it accepted leading personalities in commerce and industry as honorary members; and that it was set totally apart from the trade unions affiliated to the Bourse du Travail, which were in general made up of citizens who believed neither in God nor in the devil. ${ }^{1}$ Dalle and Rozier, of the Fédération Nationale, tried to secure the exclusion of the SECI delegation from the second congress of the Fédération Internationale des Employés, held in Brussels from 19 to 22 September 1903; Zirnheld pleaded: "We have come here in response to an appeal addressed to all associations of clerical workers, not thinking that our personal convictions would be a reason for excluding us. Our aim, I repeat, is not a religious aim and we have no other ambition than to serve, like you, the great cause of the clerical workers." With the support of the Belgian socialist delegation the congress agreed to grant credentials to the SECI delegation.

Excluded from the Féderation Nationale the SECI sent a delegation to the ninth national congress of the Fédération des Employés de France, which met at Bordeaux from is to 17 August $1902 .^{3}$ It was well-

${ }^{1}$ L'Employé, July i goz.

2 L'Employé, October 1903.

3 The Fédération Nationale des Employés was set up at a congress held in Paris on 15 and I6 July I 893. Its main support came from the Chambre Syndicale des Employés de la Seine, and its leaders included a number of socialist politicians from the Possibilist Fédération des Travailleurs Socialistes de France, Andre Gély, Lavy, Victor Dalle, and Arthur Rozier, all of whom became members of parliament. Dalle was elected in 1900 as a clerical workers' representative on the Conseil Supérieur du Travail. In 1902 the federation claimed to have 15,460 members in 17 organisations, of which 8 were in Paris and the rest in Amiens, Angers, Le Mans, Nantes, Orléans, Rouen, Toulon, Troyes and Versailles. Although it pledged itself initially to work with manual workers' unions for the complete emancipation of the proletariat, its policies became increasingly moderate and at its $\times 902$ congress it rejected a motion claiming that "the real solution to the social problem could only be obtained by social revolution" and warned its members against the disadvantages of strike action, compared with direct negotiation with employers, appeals to public opinion and approaches to public authorities.

The Fédération des Employés de France was set up at a congress held in Beauvais, on 14 and I5 August 1894 , attended by delegates from a number of trade unions which were opposed to the revolutionary temper of the Fédération Nationale and to the dominating role of the Paris trade unions within it. It had its headquarters first in Beauvais then in Rouen ( 1897 ). It sent delegates to, the sixth national congress of the Fédération Nationale, and to the international congress in 1900 , but opposed the idea of a single federation of 
received and thereafter the SECI was regularly represented at the congresses of this federation and its delegates served as chairmen of committees. Viennet, presenting a report on the weekly holiday to the 1907 congress at Lyon, said that his task was easy, as the ideas of his union fitted in exactly with those of a majority of the members of the committee. ${ }^{1}$ Summing up relations with the federation some years later he said: "It is worth making the point that most of the leaders of the federation profess philosophical ideas which are far removed from Catholicism, but they behave with perfect tact in their dealings with the union of the Petits-Carreaux, recognising its loyalty to the trade."

Loyalty was a word that came easily to the lips of the leaders of the SECI, and they differed from many of their fellow social Catholics, as well as from many of their non-Catholic fellow trade unionists, in extending their loyalty to the Republic. They were untouched equally by the royalism of the Catholic right and by the internationalism of the socialist left. Most of them had been born under the Republic, they accepted it and worked within it, they were ralliés from instinct and not from political calculation. Although they were willing, even anxious to learn from the experience of other countries in the field of labour organisation and social legislation, they preferred to keep France for the French. Their constitution provided that their members should be Frenchmen; their remedies for economic difficulties frequently involved restrictions on foreign workers $;^{3}$ their courses in foreign languages were designed to train Frenchmen to work as foreign correspondents in commercial houses and to make the employment of foreigners unnecessary; they made sly digs at the foreign element in the CGT. ${ }^{4}$ And while the CGT conducted a virulent campaign of antimilitarism, the SECI prepared its members for military service with union training courses and sent off its conscripts with farewell assemblies addressed, as in, 1906, by a general officer. As the storm clouds of war gathered the SECI, far from supporting the call of the

clerical workers, because of its conviction that "politics should be excluded from tradeunion organisations, which should not serve as a stepping stone to enable pseudo-clerical workers to obtain some sort of political office." In 1902 the federation claimed to have 5,293 members, in 24 towns. Among its leaders were Adolphe and Saint-Cyr, from Beauvais, Bourdin and Vergne, from Rouen, Trénit, from Bordeaux. See Ministère du Commerce, Les Associations Professionnelles Ouvrières, Tome IV, Paris, 1904, pp. 690-7I 7.

1 La Ruche Syndicale, October 1907.

2 Viennet, op. cit., Pp. I I-I 2.

${ }^{3}$ See, for example, the report on wages, presented to the 1914 congress of the Féderation Française des Syndicats d'Employés Catholiques, which contained a proposal to limit the numbers of foreign clerical workers. Reported in L'Employé, July i914.

4 See, for example, Thévenin's article in the Bulletin Mensuel des CEuvres, 1910, pp. $48 \mathrm{r}-48 \mathrm{~g}$, with its references to the machinations of Comrade Trukosoff of the CGT. 
Second International for a general strike against war, printed an appeal from Zirnheld: "The fashion today is pacifism. Do not carry pacifism to excess. However painful war is we must admit that sometimes it is necessary... In your military service you will acquire moral qualities which will be useful to you in fighting the good fight on the social battlefield... Set off with courage, come back promoted and ready to take part with us in the daily battle to bring about the ideal of the reign of social justice and brotherhood, not forgetting the slogan, Catholics and Frenchmen for ever."1

\section{VIII}

The success of the SECI encouraged its leaders and Catholics outside its ranks to hope that its example might be followed by other Catholic workers, and from 1898 onwards it helped with the formation of unions in a number of trades - engineering, printing, jewellery, clothing, woodworking and building. The help took the form of propaganda in the youth associations and talks from SECI members on how to organise a trade union. The unions that resulted were small in membership and short-lived, and although they adopted several of the SECI's policies, such as restricting membership to Catholics, recruiting in the youth associations and formulating policies in study committees, they frequently lacked its sturdy recognition of the essential conflict of interest between the employer and the employee. ${ }^{2}$ An inter-union congress held at 14 , Rue des Petits-Carreaux on 20 December $\mathrm{I}_{90} \mathrm{O}$ brought together 60 delegates, representing a dozen organisations. In I9I 2 a number of Catholic manual worker unions which had their headquarters at I 8 , Rue de l'Echiquier moved to the SECI's offices at I 4 bis Boulevard Poissonnière and Tessier was authorised to act as their general secretary but it needed more than competent administration to build up their organisation and by March I 913 they claimed no more than 600 members. $^{3}$

More success attended the spread of trade unionism among Catholic clerical workers. After the report of the SECI delegation to the Catholic workers congress in Reims in 1896 "many people took note of

\section{${ }^{1}$ L'Employé, October i9io.}

2 The Syndicat Ouvrier de la Métallurgie, for example, founded in I 898 , declated its belief that social inequalities were one of the consequences of human existence and admitted that wages could not be uniform within the trade, but that everyone must be paid according to his intrinsic value. See L'Echo des Syndicats, I90I, passim.

${ }^{3}$ Le Mouvement Social (previously L'Association Catholique, until December 1908) Vol. IV (1914), pp. 372-377, report of survey of membership of trade unions of Catholic workers, made by La Vie Syndicale. 
the organisation to try to form similar unions in the great commercial centres of France." others as sections of the SECI. Congresses held in 1908, 1909, and 1912 prepared the way for the formation, in I91 3, of the Fédération Française des Syndicats d'Employés Catboliques, which consisted a year later of the SECI and 14 sections and 16 other affiliated unions. ${ }^{2}$ The principles on which the SECI was based were widely adopted; strictly Catholic recruitment, exclusively professional action, complete independence of the employers and careful administration of the union. The federation claimed a membership of 12,000 in 1913 .

\section{IX}

The SECI began as a benevolent society for Catholic clerical workers and evolved into a trade union. The growth began through the employment bureau, which the union took over from Brother Hiéron in 1892. Increasingly it was possible to lay down minimum scales of pay when placing members in employment; by 1914 the scales were 30 to go francs a month for school-leavers at 13 or 14 years of age and I 50 to 175 francs a month for members who had completed their military service $;{ }^{3}$ in a similar way it attempted to regulate hours and conditions of work. The SECI represented the member when differences arose with his employer. The procedure was described by Viennet. "The union informs the member of his rights. If it is asked to intervene it makes a rapid survey of the case, to see that it is not the employee's and then it proposes a fair solution to the employer. On most occasions this settles the affair. If the employer refuses to negotiate the case is taken to the trade conciliation tribunals, with the aid of the union's legal advisers. Quite large sums have been obtained [as compensation] in this way. The legal advisers consist of a number of barristers and an advocate for the conciliation tribunal."4 Zirnheld referred in 1908 to the holding of mixed conferences at which the conditions of work of clerical workers had been discussed with a number of employers and

1 Viennet, in Le Sillon, Io July i 898.

2 Sections of the SECI in Angers, Arras, Calais, Chalons-sur-Marne, Cherbourg, Laval, Le Mans, Morlaix, Nantes, Orléans, Rennes, Saint-Nazaire, Tours and Vannes. Separate unions affiliated to the federation in Amiens, Dijon, Dunkerque, Fougères, Grenoble, Lille, Limoges, Lyon (2), Marseille, Moulins, Paris (the SECI and two other unions of women clerical workers), Reims, Roubaix and Toulouse.

3 Viennet, op. cit., p. 22. Cf. Viennet's lecture at the Semaine Sociale de France, IXe Session Limoges 19I2, p. 359. "In Paris many clerical workers aged between twenty and thirty earn less than 5 francs a day. In the provinces it is by no means uncommon to find men of the same age earning wages of 110,90 and even 75 francs a month."

4 Viennet, op. cit., p. 28. 
agreement reached for the implementation of the law on weekly holidays. ${ }^{1}$ In 1913 the newly established Fédération Française des Syndicats d'Employés Catboliques adopted a programme which included demands for the ten-hour day, a one and a half hour meal break, half-day closing, the enforcement of the weekly holiday, no night work for women and children, no employment of children on street stalls, no basement work, paid annual holidays and the regulation of the period of notice.

The SECI never called a strike during this period, but it came to recognise that strike action might be an appropriate weapon in certain circumstances "in department stores and large banks". ${ }^{2}$ On the occasion of the 1907 strike at the Galeries Lafayette, called by the Chambre Syndicale des Employés de la Seine, after the dismissal of one of its members, Milianini, Viennet wrote that the SECI "supported the claims of the Cbambre Syndicale des Employés, admitted that there had been victimisation, but considered that the strike was inopportune. Even when a strike is justified it is not always opportune", he explained, "and it is advisable to take that well into account before calling it." A postal strike called in I 909 over the minister's refusal to recognise the postal workers' union brought from Tessier the comment: "I cannot remember strikers more dignified in their attitude, more moderate in their demands, more estimable in the causes of their peaceful protest."4

The SECI set great store in the opportunities afforded through representation on official bodies, and for this reason it was particularly anxious not to endanger the legal recognition it enjoyed under the I 884 Trade Union Act. It took part in the elections to the Conseil Superieur du Travail for the first time in 1901, putting up its own candidates; in later years it helped to secure the election of Artaud and Besse of the Fédération des Employés de France. It campaigned vigorously for the extension of the prud'hommal conciliation system to commercial employees; when this was achieved in 1907 it put up its own candidates and Viennet was elected conseiller des prud'bommes for the department of the Seine, in I9I I, after a stormy campaign, during which he spoke at the Bourse du Travail in Paris in opposition to the CGT's candidate, Léopold Faure.

The campaign for the establishment of prud'bommes for commerce brought the SECI into contact with ministers and civil servants; the first official deputation to the minister of commerce was undertaken

${ }^{1}$ Questions Actuelles, Is March, 1908, pp. 229-230.

2 Ibid.

- L'Employé, December 1907.

- L’Employé, April igog. 
on 2 I January I90 I ${ }^{1}$ and it opened up possibilities of parliamentary lobbying. When the issue came before the Senate in 1903, the Bill already having been approved by the Chamber, the SECI put its case in a letter sent to each senator; when the Bill was rejected it lobbied the senators, many of whom swung round in favour of the Bill, indeed, one of them, Lamarzelle, spoke to the SECI brief with such enthusiasm that the left accused him of demagogy. ${ }^{2}$

Meanwhile the deliberations of the study committee were providing an extensive programme of labour legislation; after studying the social legislation in England, New Zealand, Austria, Germany and Belgium, during the session I905-1906, the SECI came out with the following proposals for changes in the Labour Code.

I. Labour Agreements. Articles of Apprenticeship. The revision of the Act of $185 \mathrm{I}$. The determination of the articles of apprenticeship by the trade itself, to include the fixing of wages and hours of work for apprentices, compulsory technical education up to the age of 18 , under the control of the factory inspectorate, provided in schools, in evening courses or at the place of work.

Contract of Employment. The establishment of contracts of employment, negotiated by the trade unions and applying to all workers, unionists and non-unionists alike, employed by the firm making the contract.

II. Labour Regulations. The application of the Factory Acts to offices and shops. Regular inspection. The creation of university chairs in social legislation... An increase in the size of the factory inspectorate... The recruitment of assistant inspectors from workers, or ex-workers, who are members of trade unions. Full inspectors to continue to be recruited by open competition.

III. Trade Associations. The extension of the legal recognition of trade unions and trade-union federations, the granting of the right to engage in commercial activities and recognition in civil law.

IV. Labour Tribunals. Conciliation and Arbitration. Representation on Official Bodies. The extension of the jurisdiction of the conseils des prud'bommes to clerical workers.

Conciliation and arbitration tribunals; the acceptance of the principle of compulsory arbitration.

Labour councils: an absolute necessity, they ought to serve as the base for the drawing up and application of social legislation.

1 Deputation consisted of Rossin, Zirnheld and Guillebert.

2 Viennet, Bulletin Mensuel des CEuvres, 19 I4, pp. 30-32. 
Millerand's decrees must be maintained and the Bérenger Bill, to limit the powers of these councils, must be opposed.

Representation: the legal organisation of the trade should take this form - at the base, the individual, brought together, legally, with other workers in the trade, employers and employees above this level there should be trade councils, or labour councils, with the responsibility of striking a balance between the interests of employers and employees - at the top a trade Senate, representing the economic interests of the country, just as the Chamber of Deputies represents the territorial interests.

V. Labour Insurance. Accidents at work; the extension to commercial employees of the workmen's compensation Act.

Old age and sickness; the establishment of compulsory pension and sickness funds, with the triple participation of the workers, the employers and the state; the income of the funds to come from a joint contribution, on the German model, administration to be on a regional basis, under the control of the three parties.

VI \& VII. Mutual Aid and Assistance. The addition of these two sections to the Labour Code.

The first, mutual aid, to cover such matters particularly affecting the workers as mutual benefit societies, savings banks, consumers' co-operative societies, co-operative credit societies, low-rented housing.

The second, assistance, to complement and correct mutual aid. ${ }^{1}$

The leaders of the SECI realised that its effectiveness as a pressure group depended upon its restricting its action to matters directly affecting its members as clerical workers. Even though the general election of 1902 was fought largely on the religious issue, to which the members could hardly have been indifferent, Zirnheld, in an article on their electoral duty, urged them to judge the candidates on their social programme - pensions, labour legislation, the weekly holiday, the extension of the conseils des prud'bommes and the establishment of labour councils. Fervent patriot that he was, he even judged the military service issue in trade-union terms. "We are hardly competent to give advice on this question, but nevertheless we would point out how heavy this burden is for working people, and what interest there is, if the higher needs of the state can be safeguarded, in making as short as possible the period of absence of the son or the brothers, who are often the sole support of working-class families."2

${ }^{1}$ L'Employé, July 1906.

2 L'Employé, March 1902. 


\section{$\mathrm{X}$}

The activity of the SECI was greatly reduced by the outbreak of the war in 1914; the relative youth of its members meant that it was heavily hit by mobilisation; over a thousand of them were victims of the war, including the general secretary, Viennet, who was killed in action in August 1914; Zirnheld was taken prisoner in 1916. Nevertheless it was possible to raise a substantial loan from members (410,000 francs) to finance the move to 5 , Rue Cadet, necessitated by the expiration of the lease on I4bis, Boulevard Poissonnière in 1916. It was here that the post-war international conference of Christian trade unions met from 16 to 19 March 1919 , and the SECI formed the nucleus of the Comité Confédéral Français du Travail Chrétien, which represented French organisations of Catholic workers. In the negotiations which followed for the establishment of a Christian tradeunion confederation in France the role of the SECI was crucial. The Confédération Française des Travailleurs Cbrétiens, set up in November I9I9 had Zirnheld as its chairman and Tessier as its general secretary. Its practice and its principles were those of the SECI; Catholic in its recruitment; independent of the employers' organisations in its action; favouring the establishment of machinery of collective bargaining with employers and persistent pressure on government and parliament for the extension of labour legislation; ready, on its own clearly defined terms, for collaboration on specific issues with other tradeunion organisations, irrespective of their ideological basis; committed irrevocably to pluralism in trade-union organisation; strongly led, competently administered, demanding discipline from its members, but offering, through its educational services, a wide opportunity to participate in the debates from which policies emerged; well-regarded by the Catholic hierarchy, for whom the piety of its leaders was above reproach, and, through the politically active social Catholics, who had known it so long and so well, endowed with influential friends in high places. Such was the legacy of the SECI to the CFTC. 


\section{APPENDIX}

SECI MEMBERSHIP I 887 -I9I9

\begin{tabular}{|c|c|c|c|c|}
\hline September & 1887 & I 8 & end 1902 & 2,452 \\
\hline end & I 887 & 25 & 1903 & $2,8 \circ 2$ \\
\hline end & I 888 & 125 & 1904 & 3,210 \\
\hline March & I 889 & $30^{1}$ & 1905 & 3,673 \\
\hline end & 1889 & I 25 & 1906 & 3,974 \\
\hline May & 1890 & 177 & 1907 & 4,516 \\
\hline November & 1890 & 230 & 1908 & 4,941 \\
\hline June & $189 \mathrm{I}$ & $269^{2}$ & 1909 & 5,400 \\
\hline end & I $89 \mathrm{I}$ & 320 & I910 & 5,465 \\
\hline & 1892 & 413 & 1911 & 5,982 \\
\hline & 1893 & 667 & 1912 & $6,545^{3}$ \\
\hline & I 894 & $85^{8}$ & 1913 & $7,254^{4}$ \\
\hline & 1895 & $I, O O I$ & 1914 & 7,8 I 8 \\
\hline & 1896 & $\mathrm{I}, \mathrm{I} 30$ & 1915 & 8,148 \\
\hline & I 897 & 1,467 & 1916 & 8,259 \\
\hline & 1898 & 1,719 & 1917 & 8,475 \\
\hline & I 899 & 1,966 & I9I 8 & 8,832 \\
\hline & 1900 & 2,042 & 1919 & $9, \mathbf{I} 2 \mathrm{I}$ \\
\hline & 1901 & 2,258 & & \\
\hline
\end{tabular}

SECI FINANCE

I 889: contributions averaged 2 I francs a month (252 francs). I 890 : contributions averaged 64 francs a month ( 768 francs). I 891 : contributions averaged 76 francs a month (912 francs). 26 March 1889 to 25 June $189 x$ : income 1,900 francs, expenditure 1,700 francs.

Guillebert's report to the Minister of Commerce

Contributions due

1891

1892

1893

I 894
$600.50 f r$.

$\mathrm{I}, 80$ 5

2,867

$4,26 \mathrm{I}$

\section{Contributions paid}

300 fr.

1,357

2,402

$3,858.50$
$\%$

50

75

83

90

1 of which 25 active and 5 associate.

2 of which 2 I I active and 58 associate.

3 of which 549 in Sections.

a of which 807 in Sections. 


\section{Contributions due}

$\begin{array}{ll}1895 & 5,221 \\ I 896 & 5,804 \\ 1897 & 6,720 \\ \text { I } 898 & 8,492 \\ 1899 & 9,520 \\ 1900 & 10,766.50 \\ 1901 & 10,761 \\ 1902 & 12,175.50\end{array}$

Contributions paid

$\%$

4,900

93

4,848

5,234

$6,218.50$

$6,573.50 \quad 69$

7,061

$7,395.50 \quad 68$

8,914

N.B. The membership figures do not distinguish between full and associate members; the figures for contributions do not include contributions for members engaged in military service.

1906: income 26,608 francs, expenditure 23,015 francs.

Discount Purchases and Co-operative Trading

I 896: members' purchases 101,364 francs.

I 899: members' purchases 138,589 francs.

1902: members' purchases 163,000 francs; dividend distributed to members I I ,000 francs.

I9I I: turnover of the SECI co-operative society 638,088 francs; dividend distributed to members 35,000 francs. 